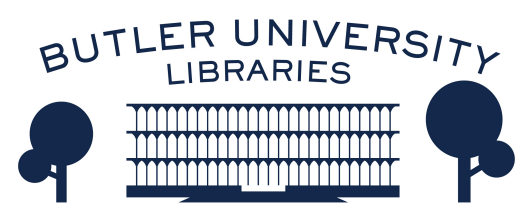

Journal of Hindu-Christian Studies

Volume 10

Article 19

January 1997

\title{
Book Review: "Population, Consumption, and the Environment: Religious and Secular Responses"
}

Antony Berger

Follow this and additional works at: https://digitalcommons.butler.edu/jhcs

Part of the Religion Commons

\section{Recommended Citation}

Berger, Antony (1997) "Book Review: "Population, Consumption, and the Environment: Religious and Secular Responses"," Journal of Hindu-Christian Studies: Vol. 10, Article 19.

Available at: https://doi.org/10.7825/2164-6279.1165

The Journal of Hindu-Christian Studies is a publication of the Society for Hindu-Christian Studies. The digital version is made available by Digital Commons @ Butler University. For questions about the Journal or the Society, please contact cbauman@butler.edu. For more information about Digital Commons @ Butler University, please contact digitalscholarship@butler.edu. 


\section{Population, Consumption, and the Environment: Religious and Secular Responses. Harold Coward (Ed). Albany, NY: State University of New York Press, 1995, 319 pp.}

LIKE AN EARLIER volume edited by Harold Coward (Ethics and Climate Change: The Greenhouse Effect, Wilfrid Laurier University Press, 1993), this book presents a range of possible responses to current global crises based on religious, philosophical, scientific, and social considerations. As a critical review of underlying beliefs and attitudes, it is also a rallying cry for collective responsibility and action, and its conclusions, as expressed in a consensus statement drawn up at the 1993 seminar on which it is based, are far too important to remain buried in a scholarly book.

Coward sets the stage by pointing out that it was Western Christianity that provided the cultural background for the most aggressive domination of peoples and nature - a view echoed by other contributors. But for all major religions, the "aggressive, self-centred attitude that has typified human interaction with the environment is unacceptable" (p.12).

In one of two baseline reviews, Kenneth Hare summarizes the extent to which the earth's surface and biosphere are being changed by humans. He warns that "self-conscious life" is beginning to bring about its own destruction, but sees hope in international science. Anne Whyte points to the exceeding of environmental limits and the irreversible damage that results, especially in the rapidly growing cities of the South. The crises must be dealt with by improving living standards, reducing child deaths, improving the lot of women, and making family planning choices available. In short those who have more must voluntarily reduce consumption to benefit those who have less. "Better social policies are therefore better environmental policies" (p.50).

Daisy Sewid-Smith begins the discussion on religious responses with a brief look at
Aboriginal spirituality, according to which all forms of life are in a state of equilibrium. To disturb this balance invites environmental disaster, though the reader is given no clue as to what this balance might look like.

For Sharon Levy, Judaism has the right approach to reconciling population versus consumption, even though for Jews, decreasing world-wide in numbers, the issue of self-imposed population control is "extraneous and absurd" (p.76). For the rest of the world, she advocates education rather than population control; consulting the Torah as the "user's manual" (p.82); caring for God's world and thus reducing wasteful habits; being humbly self-aware; and choosing to change.

Christianity's "aggressive political impact" (p.109) on the planet is the subject of a sharp critique by Catherine Keller. For her, it is modern Christian cultures that are responsible for ecologically unsustainable patterns of development, where the high rate of consumption far exceeds that of the more populous Third World. "The child who will have the most is the one the world can least afford" (p.118). For Keller "today's duplicitous Christian testament of over-population and sexual denial" (p.115) derives from Hebrew scripture with its support for the patriarchal family. Yet, her prescription is for a return to the Hebrew emphasis on justice, which regards poverty as wrong, and on shared abundance enhancing quality not quantity of life.

As to Islam, Nawal Ammar's brief review of the basis in the Qur'ān for an environmental ethic, points out that the preservation of nature is a more central theme in Islam than the notion of holy war.

For Klaus Klostermaier, though the spiritual tradition of Hinduism expressed in the practical wisdom of Indian farmers and 
workers has a message for the world at large, he "begins to doubt the effectiveness of Hindu ideas of ecology" (p.150). The traditional Hindu respect for nature that restricted interference to a minimum and that viewed natural catastrophes as the result of human violation of sacred nature is hard to reconcile with contemporary India where industrial pollution and urban poverty are widespread, a view shared in a later chapter by Mahendra Premi. Hinduism has closed its eyes to contemporary issues, preferring to repeat ancient teachings and encourage ancient ideals.

A Buddhist perspective on population issues by feminist theologian Rita Gross recalls that Buddhism values moderation and responsibility in reproduction, does not require its adherents to multiply, and does not view human sexuality as necessary only for reproduction. The Buddhist view of the interdependence of all beings implies that individual rights cannot be allowed to threaten life's supportive matrix, whether in terms of consumption or reproduction. The Middle Way favours neither "mindless pro-natalism" nor mindless consumption (p.163), neither poverty nor over-consumption. Rather, it encourages a drop in population through improvements in the quality of life.

A final religious perspective by Jordan and $\mathrm{Li}$ Chuang Paper points out that concerns over population numbers in China did not exist until recent times, and the simple ethic of unnecessary consumption sufficed. Since there was no belief in another world, Chinese culture should be more sensitive to environmental concerns than those which look to an afterworld, though with rapid economic growth, environmental problems abound in modern China.

The book also contains a series of secular responses, including arguments for the moral necessity to empower the poor (Michael McDonald), the need for a feminist approach to population control (Jael Silliman), more assistance from the North to reduce pressure on Third World resources (Elizabeth Adjin-Tettey), and the advantages of a deep ecology perspective (Yuichi Inoue). Especially interesting is Rod Dobell's critique of the religion of economics, with its predilection for wasteful, destructive technologies and usage of limited resources.

In his final summary, Coward reiterates that all religions can help to interpret the human condition in ways that temper human aggression toward nature. Though some religions make stronger claims than others, there would indeed seem to be a common vision of sufficient force to move toward a more sustainable world, as underscored in the book's final consensus statement. In its general recommendations for individuals, educators, religious and business leaders, governments, and NGOs, this declaration echoes one made a week earlier at the 1993 Parliament of World Religions. Thoughtful and sincere declarations such as these are immensely frustrating if no real efforts are being made to translate them into the actions so badly needed.

For this reviewer, this book echoes the global consensus that it is only people who degrade the ecosphere, as if natural processes that harm wildlife and people and that radically transform landscapes in human terms did not exist. Hare, for example, regards man as the problem, not conservative, sedate Nature. This view begs the question of how people on low-lying islands should regard natural sea-level rise that threatens to inundate their homes? Would right living have prevented natural climate change such as that which drove early humans from the savannas of what is now the hyper-arid core of the Sahara? What do world religions say about an autonomous nature that can and does harm people and ecosystems alike, whether through rapid landscape change, disease, or climate extremes?

Underlying many writings on the environment, including some contributions to this book, seems to be the view that a 
return to the simple ethics and beliefs of world religions would ensure that people, if not necessarily in the vast numbers of today, live full and happy lives in harmony with nature. Yet as Thomas Berry, Larry Rasmussen, Rosemary Radford Ruether, and other theologians now argue, what is needed is a radically new way of looking at and living with nature, one more in tune with the findings of science and one much more critical of existing economic and social structures. If religion has an essential role to play in a grand reconstruction, it does not seem to have found one yet.

Antony Berger

Victoria

\section{Kälì's Child: The Mystical and the Erotic in the Life and Teachings of Ramakrishna. Jeffrey J. Kripal. Chicago: University of} Chicago Press, 1995, xxi+386pp.

$K \bar{A} L \bar{I}$ 'S CHILD SEEKS to uncover the inner life of the Bengal mystic Ramakrishna. The "secret talk" found in the Käthamrta (known in English as The Gospel of $\dot{S} r i$ Ramakrishna) provides the primary source material for Kripal's textual exegesis, though other, less familiar texts are also included. Through this analysis the author arrives at some provocative conclusions: Ramakrishna was essentially a conflicted Tantric whose suppressed homoerotic urges fuelled his frequent samadhis. A misogynist as the result of childhood sexual advances by village women, Ramakrishna was later sexually preyed upon by his patron Mathur and by his female and male gurus. Finally these "secrets" were systematically suppressed by the Ramakrishna Order.

Kripal writes well, brilliantly on occasion, and presents his evidence with a fine flourish. The extensive bibliography is impressive, and Kripal displays a command over a wide body of material. Considering the author's promise, why then is the book so flawed?

While the author describes himself as a "digger" who uncovers hidden material, his methodology has been more like the rogue cop who plants evidence only to "discover" it for the sake of manufacturing his case. Betraying his own bias, the author frequently uses misleading translations to prove his thesis. Examples abound, but a couple will demonstrate Kripal's technique: Ramakrishna goes into samadhi seeing an English boy who reminds him of Krishna. According to Kripal, Ramakrishna goes into samadhi seeing the boy "thrice-bent in an erotic pose", and "stunned by the cocked hips of the boy". Yet neither of the two references cited by the author mentions "cocked hips" or an erotic pose. It simply states that the boy was "tribhanga" - bent in three places. On a different tack, "māga" is translated as "bitch" - thus verifying Ramakrishna's purported misogyny - when the word is merely a colloquialism for "woman". Other distorted translations alternately transform Ramakrishna into a pederast or an onanist.

Kripal further builds his case by quoting unreliable sources. For example, Kripal describes a particularly bizarre method Ramakrishna supposedly used to control lust, but his endnote admits that he "doubts seriously" the incident ever occurred. Inexplicably, the incident is referred to again, twenty pages later, to seal his conclusion - despite his own admission that the information is probably inaccurate.

While the author decries the Ramakrishna Order's "suppression" of literature, notably the Jivanavrttänta of Ram Chandra Datta, he neglects to mention that 